\title{
Local Wisdom in Suwuk of Javanese Spells: Ethnolinguistics Studies
}

\author{
D Ardhian ${ }^{1}$, N B Fauzi ${ }^{2}$, V Hardinata ${ }^{3}$, Warsiman $^{4}$, E Mutiarazani $^{5}$ \\ 1.2.3.4,5 Faculty of Culture Studies, Universitas Brawijaya \\ \{danyardhian@ub.ac.id1, banyubening@ub.ac.id2, vanda_hardinata@ub.ac.id3, \\ warsiman@ub.ac.id4,mutiara.echa@gmail.com5\}
}

\begin{abstract}
Suwuk (baby spell) is an alternative healing method carried out by dukun suwuk (healers) in traditional Javanese society. This healing method uses a spell text recite with massage. Suwuk serves to ward off spirits that are considered disturbing the baby, while massage is useful for relaxation. This research uses the text of suwuk from Mbah Monah, dukun suwuk from Nanggungan Village, Pacitan, East Java. Data collection using observation method. Data analysis uses language analysis at Phonology, syntax, and semantics. The results show there are inconsistencies in the phonological and syntactic levels. The suwuk is more concerned with the aspect of meaning (semantically) than the beauty of the sound since this mantra is not recite aloud, but whispered. In the institutional structure of society, suwuk shaman is equivalent to an elder. He inherited the skills of massaging the baby from generation to generation from his parents. Arabic and Javanese language marks a blend of Islamic and Javanese cultures. Islamic texts are present to avoid shirk (associate with God). The dukun suwuk profession is also useful in the solution of family problems.
\end{abstract}

Keywords: Suwuk (baby spell), Dukun Suwuk (baby healers), Pacitan, Ethnolinguistics

\section{INTRODUCTION}

In Javanese society, mantra (spell) have opposites functions: positive and negative. In a positive, the mantra is used to repel pests, bring rain, drive away spirits, and bring fortune. Granting mantra, santet (harming someone with the help of spirits) are a kind of mantra for negative things. In positive things, one form of mantra use is suwuk (baby spells). Suwuk is an alternative healing method that is well-known in traditional Javanese society, especially East Java. This method is usually combined with a ritual spray (blowing or spitting on a patient's body with a target forehead, face, or hair) and combined with massage. Suwuk also aims to expel spirits that are disturb someone, usually a small child.

In the Nanggungan village, Pacitan, East Java, there is a healing method by using suwuk which are usually used to cure fever in infants. Although in modern era, people still believe in this method. For them, suwuk is the most effective technique in treating babies who are fussy or crying. They assume fussy babies or crying for a long duration are considered to be disturbed by spirits. 
Suwuk is usually practiced by a dukun suwuk (traditional healers). In traditional Javanese society, dukun suwuk have a central role as guardians of cultural heritage. They are considered to have the ability of linuwih (expert associated with the invisible things of metaphysics). They have the power to communicate with spirits so that dukun suwuk can control the creature whether to bring it or drive it away.

Even though it is considered ancient, in fact until now suwuk is still used even though it has been modified. This modification is due to a mixture of cultures, for example with Islamic and Javanese culture so that this modification is considered necessary to touch the religious Islamic community who rejects mysticism and is not considered ancient. For some traditional Javanese, throughout his life, there have always been incantations that have started from the womb, born, grew up, married, to death. It can be said that suwuk are always present in the period of traditional Javanese society.

Many experts different view about dukun suwuk. The difference lies in who gives the suwuk. In Javanese society, suwuk can be done by parents (father or mother), people who are elder in the family (such as grandfather, grandmother, uncle, aunt or who have blood offspring with patients), or dukun suwuk. The second difference lies in the media. There are several media that are used, such as water (usually to be sprayed into the patient's body), or using blowing on the patient's body, and there are also using traditional medicine.

Shamans based on [1] research are divided into 13 types. In this category, dukun suwuk is included in the shaman massage because it combines using massage techniques in the healing process. Regarding the shaman, this means that people who are experts in healing use suwuk media. The context of meaning is then run away because suwuk can be done by people who are not considered shamans. However, it is more for people who can heal and trusted by using suwuk. The lexical meaning of the phrase dukun suwuk then experiences an generalization to the contextual meaning, namely the person who is trusted to be able to cure the disease. So, suwuk is not limited to shamans (dukun), but it can be people who are trusted to be able to cure diseases, especially by using suwuk.

Related to cultural meanings, especially in traditional Javanese society, suwuk is still entrusted to a healer because suwuk is not only limited to spell shipping, but also to massage techniques. Related to the limbs blown with suwuk, it depends on the local wisdom of the local people. There is a place that blows the suwuk spell on the head, on the forehead or a sick limb.

Several studies related to health spells have been carried out. However, these studies focus more on the study of form, function, and meaning, such as [2], [3], [4], [5], [6]. The research focuses less on suwuk spells, especially its linguistic studies. There are two recent studies on suwuk spells, namely [7] and [8]. Both focus on suwuk spells, especially on the cultural anthropological aspects. The study also focuses on suwuk spells that are not focused on baby patients. There is also less discussion about language aspects. These studies provide space to be equipped. This study focuses on the ethnolinguistic aspect by focusing analysis on the lingual aspects of phonological, syntactic, and semantic analysis, and local wisdom that emerges in suwuk, including its social and cultural aspects.

\section{RESEARCH METHOD}

The data in this study is the text of the suwuk baby spell. The data source was taken from a baby healer, namely Mbah Monah. Mbah Monah is one of the most famous baby healer attendants in Pacitan having his address at Nanggunggan Pacitan Village, East Java. Data is collected through observation. Data were analyzed by analyzing phonological, syntactic, and 
semantic aspects, and uncovering aspects of local wisdom. Mbah Monah opens practice every day, except Friday. The following is the data on the suwuk baby spell.

"ASSALAMUALAIKUM WANGALAIKUM SALAM,

ASYHADU AN LAA ILAAHA ILLALLAH, WA ASYHADU ANNA MUHAMMADAR

ROSULULLOH.”

TIR ITIR

SI JABANG BAYI KADADIYAN SAKING BANYUNE PELI,

DIPARINGI SIREP LEREP SAKING KERSANING ALLAH,

ALLHUMMA SAYYIDINA MUHAMMAD WA'ALA SYAYIDINNA MUHAMMAD."

\section{RESULTS AND DISCUSSION}

The phonological analysis here serves to see the number of words and syllables used in the structure of the mantra text. This is related to how these words and syllables form cohesiveness, mainly associated with sound harmony.

Table 1. Number of Words and Syllables in the Suwuk Baby Spell

\begin{tabular}{lccc}
\hline Structure & Line & $\begin{array}{c}\text { Number } \\
\text { of Words }\end{array}$ & $\begin{array}{c}\text { Number } \\
\text { of Syllabes }\end{array}$ \\
\hline Greeting & 1 & 7 & 15 \\
& 2 & 9 & 25 \\
Content & 3 & 2 & 3 \\
& 4 & 7 & 16 \\
& 5 & 6 & 15 \\
Closing & 6 & 8 & 21 \\
\hline
\end{tabular}

The number of words and syllables above does not reveal a standard structure. There is no coherence and harmony in the number of words and syllables (inconsistencies) so that when viewed from the element of beauty, the suwuk spell is less visible. This could be due to the fact that it focuses more on the meaning built in it than the form itself. It is possible, in a larger analysis (syntactic level) something similar will happen.

In addition, taking into account the number of lines that appear (6 lines), that suwuk spell includes the short category of mantra. This indicates that suwuk spell is recited with no need for a long duration and depend on the massage process. In addition, there is incoherence in its structure, namely greeting, content, and closing. The unity of meanings is "detached". When viewed from the type of meaning, the greeting in Arabic, the contents contain prayer and hope (in Javanese), and the closing contains shahadah (in Arabic). This indicates that each structure is recited out not directly, but gradually.

The syntactic analysis serves to see the use of clauses and sentences in the row of suwuk spells. Syntactic analysis is very useful to see how the power of a mantra appears in its lingual form. 
Tabel 2. Sintactic Analisys and Number of Clauses and Sentences

\begin{tabular}{|c|c|c|c|}
\hline Text & Structure & Clauses & Sentences \\
\hline $\begin{array}{l}\text { Assalamualaikum Wangalaikum salam } \\
\text { Peace be upon you } \\
\text { Ashadu alla ilaha illallah wa ashadu anna } \\
\text { muhammadarrasullullah } \\
\text { I bear witness that there is no god but Allah and I bear } \\
\text { witness that Muhammad is the Messenger of God }\end{array}$ & Greeting & 2 & 2 \\
\hline $\begin{array}{l}\text { TIR ITIR } \\
\text { (phonestemic word: meaningless) } \\
\text { Si jabang bayi kadadiyan saking banyune peli } \\
\text { The baby created from semen } \\
\text { Diparingi sirep lerep saking kersaning Allah } \\
\text { Hopefully quickly be healed from fever because of God }\end{array}$ & Content & 1 & 2 \\
\hline $\begin{array}{l}\text { Allahumma sayyidina Muhammad wa'ala sayyidina } \\
\text { Muhammad. } \\
\text { O God, give mercy to our Lord Prophet Muhammad and his } \\
\text { family }\end{array}$ & Closing & 1 & 1 \\
\hline
\end{tabular}

The table above shows the syntactic pattern between structure and ideational sentences, namely greeting, content, and closing, which show less unified patterns. The sentence pattern shows a pattern (2-2-1), while the clause pattern shows $(2.2-0,1,1-1)$. This pattern looks messy. This is different from the mantra patterns in general. Ideational sentences between greeting, content, and closing as disconnected and less comprehensive. This indicates that the baby spell is more concerned with the power of meaning than form. Besides that, suwuk spell is recited in a whisper so that beauty is not too considered.

\subsection{Semantic Analisys}

Semantic analysis is used to see the relation of meaning that is built between structure and sentences.

\section{Assalamualaikum Wangalaikum Salam}

Salam is not intended for patients, but for "spirits" that disturb the patient's body. Salam also serves as a prayer of salvation to patient.

Ashadu alla ilaha illallah wa ashadu anna muhammadarrasullullah

Syahadah is the witness of Muslims to God. The recitation serves as a notification to spirits residing in the patient's body that the healer is a Muslim. If these spirits are also Muslim, they will "help" the healer to get out of the patient's body. However, if these spirits are not, this creed serves as a "threat" to get out of the patient's body.

Tir-itir

Tir-itir refers to the indirect meaning, namely water dripping from a small hole. It is analogous that the semen dripping from the male genitals is tyrannical. The use of this phonesthemic word is more about the function of euphemism. In Javanese society, matters related to sex are taboo so that the use of taboo words will be replaced by other, more subtle words. 


\section{Si jabang bayi kadadiyan saking banyune peli}

The text above shows the beauty of rhythm, namely $-y i$ in babies and - $l i$ on peli. The word peli is male genitalia. In Javanese, the word peli is a taboo word. In the text, it is still used to show the beauty of sound. This is a little contrary to the previous text.

Diparingi sirep lerep saking kersaning Allah

Sirep lerep phrase is a form of affirmation to expect the recovery of patients from spirit disturbing. This activity is blessed by God. This indicates the intention that if spirits still disturb the patient, he has resisted God.

Allahumma sayyidina Muhammad wa'ala sayyidina Muhammad

It also serves as an affirmation that disturbing the patient also means disturbing his gods and his prophets that it is a big sin. There is nothing else that the spirits do to get out of the patient's body.

\subsection{Local Wisdom in Suwuk}

The majority of the Pacitan people are Muslim. The suwuk spell is a form of language creativity so that this tradition can still be trusted. The salam, syahadah, and salawat is a way to convince people that this practice is not animism, dynamism, and shirk. With that situation, the practices of non-Islamic shamanism will be abandoned. So, this suwuk culture follows the changing times from non-Islam to the Islamic era in order to survive.

The presence of inconsistencies in the form of both phonological and syntactic structures indicates that the power of this spell is actually not the recite, especially in loud readings, but to instill suggestion. Suwuk spells are not the main media like spells in general that the mantra serves to "invite" spirits to help the healers (dukun suwuk) in practice. Healers and patients perform special rituals before reciting the spell, whether fasting, providing media, such as seven flowers, slaughtering an animal (usual livestock), or other activities, such as bathing in the middle of the night. This is not done in a suwuk. The healers must also understand and master massage techniques. Suwuk spell is intended to enlighten suggestions or add confidence, or more to prayers offered to the Creator. Therefore, Mbah Monah did not hold a special ritual before the massage.

Being a dukun suwuk is a mandate from the Creator to help others. Because traditional birth attendants are trustworthy professions, traditional birth attendants do not attract tariffs. Giving from the community is accepted as is, whether in the form of money or groceries. If the people in need do not have these abilities, the dukun suwuk will be very sincere to help. In addition, the acculturation of Islamic + Javanese culture in the eastern Mataraman people is still exalted. People still cannot leave the Javanese tradition, but also mediates Islam tradition. Things that are related to people's needs are always associated with these things, whether it is a selametan event, Thanksgiving, treatment, or building a house.

This profession cannot be learned outside the descendants of posterity. Being a dukun suwuk is a mandate to help others (usually because of wangsit (inspiration from God or ancestral spirits trough dreams), and sudden expertise. This profession does not consider market and economic principles so that service competition does not occur. This profession is also not disseminated in the form of training.

In the institutional structure, the dukun suwuk is an informal sector that has no structural, but functional position (same as traditional elders (pinisepuh). The profession of dukun suwuk in 
Javanese society can be equated with other social functions, such as kyai ( Islam leaders) or traditional elders.

The dukun suwuk profession is a manifestation of local wisdom. This suwuk massage technique gets a place in the hearts of traditional Javanese people. This is a local genius that is different from other regions, especially people outside Java. This difference can be seen from the text, massage techniques, and also the massage process. The specificity of knowledge possessed by the people is very useful in supporting the sustainability of life. From that, the healers is a legacy of local wisdom that needs to be preserved both its oral traditions, massage techniques, and intimacy and hospitality are woven between healers, patients, and their families.

In this era, people still need an alternative in medical decision making. The initial advice from a dukun suwuk is needed to determine how the process of handling the disease, whether it can be handled by a healers or following the medical process. Dukun suwuk is also useful for solving family problems. During the healing process, communication was carried out between the dukun suwuk and the patient's parents. If patient parents feel there is a problem, usually family problems, advice and guidance from the dukun suwuk are also heard. So, dukun suwuk also functions as an "impromptu psychologist". They must also understand the social conditions faced by the community. They become a source of social information. This social relationship makes they become 'elder' to the community. This condition makes dukun suwuk become healer, elders, psychologist, and local wisdom preserve.

\section{CONCLUSIONS}

In general, the spell has an order of sound patterns and clauses in shaping beauty when the spell text is recited, especially with a loud voice. In phonological and syntactic analysis, suwuk baby spell text in Nambangan, Pacitan, East Java has a sound pattern and an uncluttered clause pattern. This indicates that the spells were recited not loudly or even sounded like a mantra in general, but whispered. In addition, the incoherence of meaning in greeting, content, and closing indicates that this mantra is recited not together, but in parts, according to the stages of massage. From this, the message spells are actually considered more skill in massaging than the suwuk mantra itself. The presence of this mantra is more about raising the suggestion of the dukun in handling patients.

The suwuk baby shaman is a derivative profession. Expertise is obtained from parents or ancestors. In the community structure, a suwuk baby shaman is equivalent to a community leader. The shaman also receives medical treatment from the doctor or paramedic when the patient is not treated. There is no competition between the shaman and modern medicine, it works together. Local wisdom in massage techniques should be maintained as medical functions, familiarity, and family problem-solving.

\section{REFERENCES}

[1] C. Geertz, "Religion of Java," 1976. [Online]. Available: https://monoskop.org/File:Geertz_Clifford_Religion_of_Java_1976.pdf. [Accessed: 18Apr-2019].

[2] Fatimawati (Universitas Muhammadiah Malang), "No Title," Universitas Muhammadiah Malang, 2016.

[3] A. Agus, B. Nasution, and M. I. Nasution, "SASTRA LISAN MANTRA PENGOBATAN DI KENAGARIAN TALU KECAMATAN TALAMAU KABUPATEN PASAMAN BARAT," Bhs. dan Sastra, vol. 1, no. 3, pp. 1-14, Jun. 2013. 
[4] 121111132 ABDULLAH SYAROFI, "BENTUK, MAKNA, DAN FUNGSI DALAM MANTRA PENGOBATAN DUKUN DI KABUPATEN LAMONGAN,” Jul. 2015.

[5] B. Lingual Tawa Pengobatan Tradisional Minangkabau and F. Usman, " $\square$ Fajri Usman BENTUK LINGUAL TAWA PENGOBATAN TRADISIONAL MINANGKABAU (ANALISIS LINGUISTIK KEBUDAYAAN)."

[6] T. Rotty and F. Lumempouw, "MAKNA TOKOH PENYEMBUH MASYARAKAT TOMBULU," Duta Budaya, p. 12, 2013.

[7] M. Iftia, "SUWUK, Metode Penyembuhan Penyakit Berbasis Etnomedisin di Era Modern (Studi Kasus Desa Jatiarjo, Kecamatan Prigen, Kabupaten Pasuruan,” 2016. [Online]. Available: http://pimnas29.ipb.ac.id/index.php/2016/08/11/suwuk-metode-penyembuhanpenyakit-berbasis-etnomedisin-di-era-modern-studi-kasus-desa-jatiarjo-kecamatanprigen-kabupaten-pasuruan/. [Accessed: 18-Apr-2019].

[8] Y. Yusdiawati, "SUWUK (Etnografi tentang Pengobatan Tradisional Etnis Jawa di Desa Aek Loba Pekan Kec. Aek Kuasan Kab. Asahan),' Universitas Sumatra Utara Medan, 2013. 